\title{
Socio-economic impact potential of agro tourism activities on Desa Wawasan Nelayan community living in Peninsular Malaysia
}

\begin{abstract}
Agro-tourism is a tool that has been widely used around the world for the purpose of intensifying the socio-economic aspects of the local community. Malaysia is supportive of this tool. The main objective of this paper is to unveil the potential socio-economic benefits that can be offered by the agro-tourism activities to progressive fishing communities or locally known as Desa Wawasan Nelayan1 community in Malaysia. Data were gathered through document analyses. The qualitative studies concluded that agro-tourism can be the impetus for sustainable development of Desa Wawasan Nelayan community.The benefits include enhancing their social empowerment system, strengthening their social ties and developing their social skills and relationships, increasing the income of local community, diversifying and intensifying the economic activities, providing job opportunities and alleviation of poverty. Thus, agro-tourism has the potential to raise the consciousness of the selected community regarding sustainable development.
\end{abstract}

Keyword: Agro-tourism; Community development; Sustainable development; Economic development; Social development 